DOI 10.18551/rjoas.2019-01.08

\title{
THE REPRESENTATION OF AFRICAN AMERICANS IN FILMS «I AM LEGEND» AND «WORLD WAR Z»
}

\author{
Aprilia Grisca Ayu \\ Master's Degree Program in Human Resources Development, Postgraduate Program, \\ University of Airlangga, Indonesia \\ E-mail: griscaaa@gmail.com
}

\begin{abstract}
This study describes about the representation of African-American characters in I am Legend and World War Z. This research purposes to examine wheter the 'bad' stereotypes of African American still exist or not because both film, represent most African Americans as positive characters. In the analysis of the study, the researcher uses qualitative method which the main theory used is Stuart Hall's Representation. In arranging the analysis, the researcher will analyze the experience of African-American character of both films, and also analyze the main character from World War $Z$ which is a white American to reveal the representation beyond the appearance by explaining the non-narrative aspects which are choosen such as shot, angle and lighting. After applying the theory in the analysis, this study discovers that there will be a certain meaning when African-American characters are played as the main or good characters and they cannot be as same as the White Americans. It shows that the discriminatory practice in America is not dissappear, because it just goes "undergound" which means racial inequality still become a major and pressing problem until today.
\end{abstract}

\section{KEY WORDS}

African-American, racial discrimination, representation, characters, stereotypes.

Racism has been a controversial issue in terms of politics and social-economics for many years. In America, racism is also considered as a "spoken" word, which means that people who belong to non-white race will always be blamed by the white American society. In March 1968, the US Commission on Civil Rights published "Report of the National Advisory Commission on Civil Disorders" emphasizing the significance of racism in American life. According to this report, the white society has never fully understood that white society is deeply implicated in ghetto (which means a group of society whose members are minorities due to social, legal, and economic pressure). This implies that the central paradox and the first standard in America is race. Thus, in the surface Americans seem to have already accepted the existence of African Americans, yet implicitly African Americans can still feel some kind of denial to their existence. From the beginning, America's politics is based on the principals of white supremacy (Wynter 3). White supremacy is the belief that the whites are more superior than any other races and they dominate the non-whites politically, economically and socially.

Since 1753, the acceptance of African American descendant as an American citizen has become a debatable case because it is againsts white superiority (Jorgensen 233). White superiority has long believed against the existence of any other races except for the white Americans until now. Current news in workers.org shows that black workers have been held at bay with the least pay; whether urban North or rural South, black workers are still exploited to the highest degree. Even though black people have already made an effort to be racially equal with the white and all other people in the world, they would have to wait and survive up to five decades from 1950s to 2000s to reach their real equality (Bracey 41-43). However, the problem of racial discrimination has to be faced and solved.

Black people in America or known as African Americans are stated so because they have the blood of African from their parents, so their genetic is also African but they are living in American land which is not their homeland (Tyndall 57-61). Meanwhile, the Office of Management and Budget (OMB) in the United States Bureau 2010 defined African American 
as a person who has the origins in any of the Black racial groups of Africa. It includes respondents who are reported entries such as African American; Sub Saharan African entries, such as Kenyan and Nigerian; and Afro- Caribbean entries, such as Haitian and Jamaican (2). Thus, it can be concluded that African Americans refer to the people of African descent who live in America and hold American citizenship.

Nowadays, in America, there has been a large number of African Americans in the middle class society. Based on the data from the United States Census Bureau 2010, the number of African Americans who live in United States reaches 12.6 percents of the total population. It has grown about 12.3 percents, which results in African American being the biggest "other race" in the United States of America. As a part of American population, African Americans have given a substantial contribution to the American culture, especially in arts and literature. The evidence of their contribution is the existence of African American artists, actors, singers, and authors that include Will Smith, Ruby Dee, Paul Winfield, Rihanna, Bruno Mars, Toni Morrison and many more. Nevertheless, public recognition toward these African American figures does not mean that racism has totally been disappeared in America. In fact, it just goes "underground" since racial inequality in America still becomes a major and pressing problem (Tyson 359-367).

Nowadays there are many African Americans who succeeded in the world of entertainment or even politics, yet it is not that easy to be African Americans because they are not accepted easily in American society although they have the same way of acting, speaking, and thinking like other Americans. According to Chima and Wharton, for decades, African Americans have been excluded from participating in most of desirable jobs and institution. The major problem which African Americans face includes Employment process biases, channeling into "minority" positions, lack of access to network and mentors, and etc. (1). Not only in the living practices, the discriminatory practices towards African Americans also occur in the work of art and literature, such as novel, drama, and film. In many Hollywood films, the villains weremostly given to African American actors, for example in the film Bad Boys and Blood Diamond. The African American characters were often the ones who act against the white protagonist characters. However, in some other films we may see African American actors starring as protagonists in films such as Men in Black and I am Legend. Thus, there are various ways in which American films represent African American characters. In the past, African American actors mostly played only in black films and acted as the antagonists, but now we can also see many African Americans become the protagonist in major Hollywood films. Therefore, the variety in the depiction of African Americans in films becomes an interesting subject to analyze in this study that will reveal the representation of African Americans in Hollywood films.

By looking at the issue on the society, then the reseacher decides to analyze two films; I am Legend and World War Z. I am Legend is an apocalyptic film produced in 2007 by Warner Bros. Entertainment Inc., which is fully integrated, broad-based entertainment company and a global leader in the creation, production, distribution, licensing and marketing of all forms of entertainment and their related business since 1927, and directed by Francis Lawrence which starring Will Smith. The setting in the film is in 2012, so we can see how the director can imagine the issue of the end of the world in film.

The film starring Will Smith is set in 2012, which reflects how the issue of the end of the world in film as predicted by the Mayan has inspired the filmmaking. This film portrays a very smart scientist named Robert Neville (an African American), who cannot be contaminated by an unstoppable and incurable man-made virus. Neville is the last human survivor in what is left of New York City and maybe around the world. He is just accompanied by his dog, Samantha. Neville can be the only survivor because he cannot be affected by the virus. He is desperate to find any other survivor who might be out there until there is a woman named Anna and her son, Ethan,who heard Neville on the radio and suggests him to follow them to the safe colony. After the infected found Neville's house and destroy it, Neville brings Anna the blood of the cured infected and ask her to bring it to the colony without anyone knowing how he struggles to find the vaccine. 
Unlike the previous, World War Z, an apocalyptic film starring Brad Pitt, was produced in 2013 by Paramount Pictures, a production company which was established since 2002 by Brad Pitt, and directed by Marc Forster. The film is about a former UN investigator in Philadelphia, Gerry Lane and his wife, Karin with their two daughters, Rachel and Cony, who are trapped in the attack of-a mass of zombies. This circumstance forces Gerry to travel to several countries in order to find the vaccine.

In doing this study, the researcher wants to look for the African American characters who are portrayed differently, which African American in I am Legend is the main character, while in World War Z African Americans are the supporting characters. In the World War Z, the main character is the white American and it becomes the researcher's interest in comparing the main characters of both films because it can help the researcher in revealing how African American characters are represented through these two films.

In conducting the analysis and discussion, the researcher will use the Representation theory by Stuart Hall as the tool to arrange the analysis because the researcher wants to find out the representation of African American characters through these films. Stuart Hall (1) defined the word representation as the using language to say something meaningful about, or to represent, the world meaningfully to other people. It indicates that representation is a process of production and changing meaning between members of culture.

\section{LITERATURE REVIEW}

The researcher will use the representation theory by Stuart Hall as the main tool to analyze I am Legend and World War Z films.Stuart Hall (1) defined the word representation as the using language to say something meaningful about, or to represent, the world meaningfully to other people. It indicates that representation is a process of production and changing meaning between members of culture. Hall claims it is not that simple. Hall explains about how we recognize all the things around us, of how we give meaning of things through languages, and communicate them in ways people are capable to understand.

Within the process of representation there are subjects that represent something which is called as the representative. The representative has the power to present the represented so that it can be assumed that the representative is powerful. On the other side, the represented is considered powerless since they are not able to present themselves. The inequalities of power between the representative and the represented create stereotyping in which the powerful representative makes the images of the represented based on their idea.

Nowadays we can see many positive images of African-American character such as captain, police, scientist, and etc. in the films, whereas the director of the films is the white American. From the explanation, the researcher wants to analyze films I am Legend and World War Z which have the two important points of the theory of representation, they are representative and the represented. The representatives could be social actors who use the conceptual system of their culture and other representational system to construct meaning. The representatives for these two films are the people behind the scene include the director and producer because these people have the power to create the represented. While the represented itself, are the characters inside the films that are not able to represent themselves. The African-American and the white American are represented through different stereotypes and construct their own meaning. The meaning itself is a construction. The meaning is constructed through the representational systems (Hall 25).

Hall involved two system of representation. The first is there is a "system" by which all sort of objects, people and events are correlated with a set of concepts or mental representation which we carry around in our heads. The system stated becomes the important thing to give a meaning to the world, because in giving meaning, it is based on the system of concepts and images which formed in people's thoughts which can stand for the representation of the world. Language becomes the second system of representation because it involves in the overall process of constructing meaning. People only able to represent meaning when people have access to a shared language (17-19). 
There is a term of sign I which means the general term for words, images, or sounds which carry meaning. Signs are organized to language and it is actually a common language which enable us to translate what are in our brain into words, sound or images, and to operate this as language, to express meanings and communicate thought to other people.

Hall stated in the book that there are three theories of representation, those are reflective approach, intentional approach and constructionist approach. For those three theories of representation, the researcher temps to apply the constructionist theory because the researcher as the researcher can also creates the meaning of African American representation in the films. Moreover, it has to be related to the contemporary condition of African Americans in society and the theory applied. In constructionist approach, the researcher may construct meaning using the representational system called concepts and signs. Constructivists do not deny the existence of material world, where things and people exist, and the symbolic practice and processes through which representation, meaning and language operate. However, it the language system used which creates meaning, not the material world. Representational system captured in the film consists of the image we are looking at through the camera. It is still the meaning depends on its symbolic function not the material quality.

Beside use the representation theory by Stuart Hall, the Researcher will also apply the non-narrative theory by Louis Giannetti to reveal what is not told in the narrative aspect.

\section{METHODS OF RESEARCH}

The analysis of this research is using qualitative method. Creswell claims that qualitative research is a meaning to explore and to understand the meaning individuals or groups based on the social or human problem. The process of research involves appearing questions and procedures, data analysis inductively building from particulars to general themes, and the researcher making interpretation from the meaning of the data (4).

The objects of the analysis as well as the the primary data are I am Legend and World War Z. The researcher chooses Representation theory by Stuart Hall as the primary theory. Besides the theory by Stuart Hall, the researcher will also need the secondary sources include other related books, internet sources, magazine, journal article and many more to strengthen the analaysis.

The data are collected to obtain the main focus of analysis. For the data from the films, the researcher will collect and divide to several subheadings of analysis which will go to the answer of the statement of the problem. If the researcher unable to discover the representation to answer the statement of the problem, the researcher need to capture the certain frame which provide certain meaning to strengthen the analysis.

In the data analysis also involves collecting open-ended data, based on arranging general question and developing and analysis from the information of the sources (Creswell, 183-184). Because the object of analysis in this study are films, it will be very important to analyse the data by applying the narrative and non-narrative aspects. For getting the data of the representation of chosen character, this study conducts the narrative and non-narrative analysis.

\section{RESULTS AND DISCUSSION}

The researcher would like to determine the representation of the African American characters which against the stereotype. For many years, African Americans are stereotyped negatively. Some experts have made the stereotypes for African Americans since couples of years. However, the researcher finds some of the stereotypes given by the experts have been changed from the year of 1940 s to recent situation. The changing of the stereotypes can be seen through the films.

By the late twentieth century, Black cast and and black theme-oeriented shows have already appeared in the United States. In the shows, there already casted the African Americans play as the leader (Gray 78). The role of Amfrican American leader can be seen 
in I am Legend film. In I am Legend, the Main (African American) character is named dr. Robert Neville who is a Leutenant.

As the colonel with many soldiers, Robert and his family are protected and become the important family to be primarily helped.

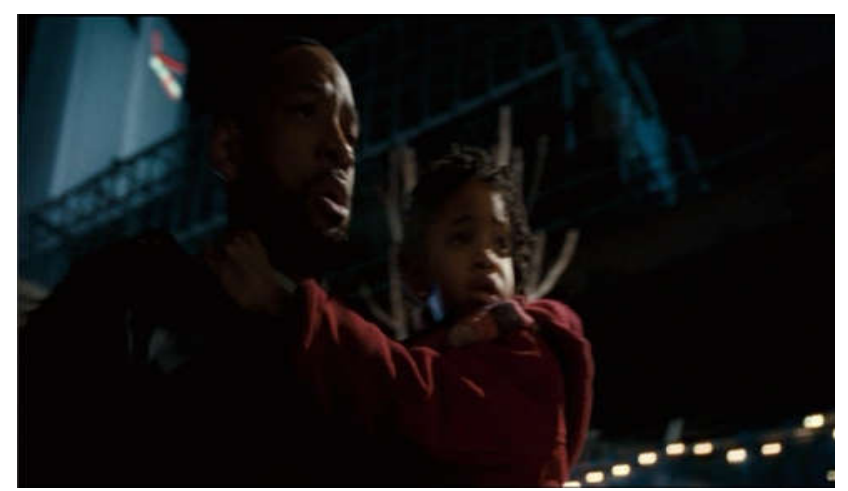

Figure 1 - Robert carries up Marley to be evacuated (00:39:46)

Mike: Keep the colonel and his family between us and don't let anyone stop you (00:39:38).

As Stuart Hall mentioned that representation is the production of meaning of the concept from people's mind through language (3). In a film, we can use everything as the language, wheter it is the sound, the picture and the dialgoue and all of those languages carry meanings. The researcher obtains the language of representation is from the picture of the film. From the angle, Robert and his daughter are taken from the low angle. The meaning of Robert's representation is supported by the non-narrative theory by Gianneti, which states that picture taken from the low angles is to heighten the importance of the captured subject (15). Means Robert is powerful as the colonel and the soldiers honor him and his family. It may come representation of Robert Neville as the honorable colonel.

Other dialogue shows (00:41:25):

Robert : Get your hand off of my wife. Get your hands off.

Marley : Mommy!

Mike : Stand down. Lieutenant

Robert : Scan her again. Get your hand off of her.

Mike : Stand down.

Robertt : Scan her again. Stand down. Stand down, soldier, stand down! I am lieutnant Colonel Robert Neville. I am ordering you to scan her again. Scan her again.

Soldier : Alright, scan her again.

The dialogues show that Robert Neville has the power to order the soldiers who are Americans. This explains that an African American still have a power in United States. His order is obliged by the soldiers, although it is debatable. However, the decision is taken as the order from Robert Neville who is an African American. From this scene, the African American is represented as a good leader and it is clear that this play against the Odum stereotype of Negro in general was not capable of taking great responsibility or of assuming leadership. The one who dominate in the film is the African American although he is in a white man's country. African Americans prove themselves to be able to have the high rank position than the Whites. However, the white shoulders have to obey the African American because based on the rank, the African American is higher.

Blacks have made great strides in the military since it was integrated 60 years ago, but they still struggle to gain a foothold in the higher ranks, where less than $6 \%$ of U.S. general officers are African-American (usatoday). This data show that the African Americans are capable to be in the high position in military service. For the context of this film, the United States Department of Justice"s Bureau of Justice Statistics (2007) reported that in 2006 the number of inmates in state and federal prisons increased to over one and a half million from 2005 (U.S. Department of Justice, 2007). 
In I am Legend, the African American character is Robert Neville and he plays as the major character. While in World War Z, the major character is Gerry Lane who is a White man. One of the minor African American characters in World War Z is Thierry Umotoni. Thrierry Umotoni is a Deputy-Secretary General of United Nations.

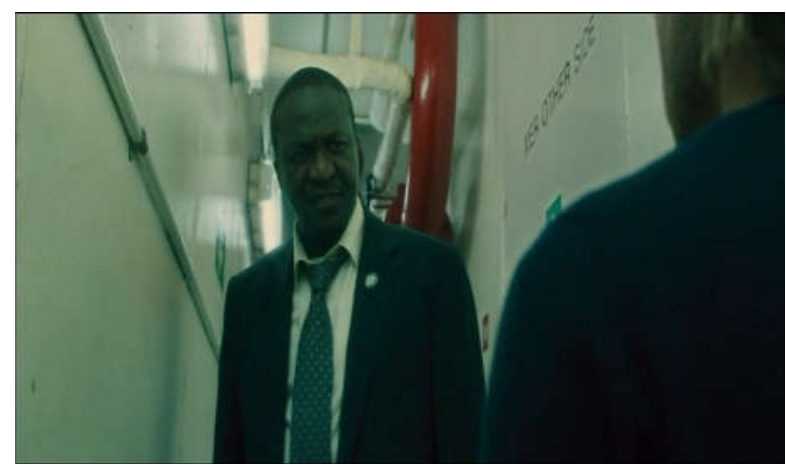

Figure 2 - Thierry talks to Gerry on the Ship (00:29:51)

From the shot, it is taken by the medium shot from the low angle which clearly means that Thierry is more Powerful than Gerry because low angle heighten the importance of the object (Giannetti 15). It also explains Gerry's character where the camera puts in his back as the object of Thierry's dialogue. This also explains the dialog between Gerry who sees Thierry in front of him as being powerful because Gerry has to obey what Thierry wants in order to get a safe place for his family.

This can be examined by the constructionist approach of representation theory, that the researcher discover a reflection of the reality constructed in this film. Years before this film was directed, there had been Kofi Annan as a Secretary-General of United Nations, and in 2013 World War Z shows the African American character as the Deputy-Secretary General of United Nations. The researcher constructs that this film is going to recall the viewers' mind that the African Americans are able to have a job in the United Nations with the high position.

There are also some African American characters appear in World War $Z$ as the minor character beside Thierry. In the film, there is an African American acts as army.

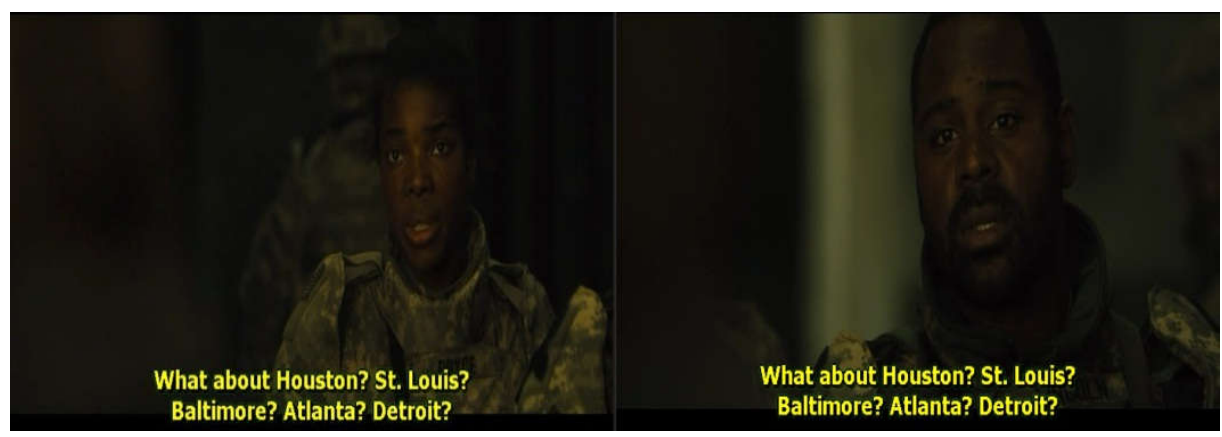

Figure 3 - Two African Americans as Army (00:41:55)

The two pictures above, are the depiction of African American army. They are worked as an army in South Korea. The role of African American characters as and army shows that now African American has the same rank as the Whites. They are in the same military order, and placed in the same place. Since 2010, there has been already 2.4 million African Americans military veteran in the United States. It implies that African American is started to have the racial equality with the Whites when they earn the same occupation.

The data explained by Entman and Rojecki (83) of African Americans that they were more likely to be shown in street or jail clothing than Whites (54 percent versus 31 percent). However, it has the reverse meaning when we take a look at the African American roles in these two films. They have a really good job. They become colonel, doctor, policeman, army, 
and also United Nations officer which generally need big effort to have those jobs and African Americans can have them.

According to Jackie Hogan, African American tends to be close with nature, such as animal and other living things. They are specializedd by virtue of their mystical powers and their primordial ties to Nature. They can communicate both telepathically and through song with animals and with each other (68).

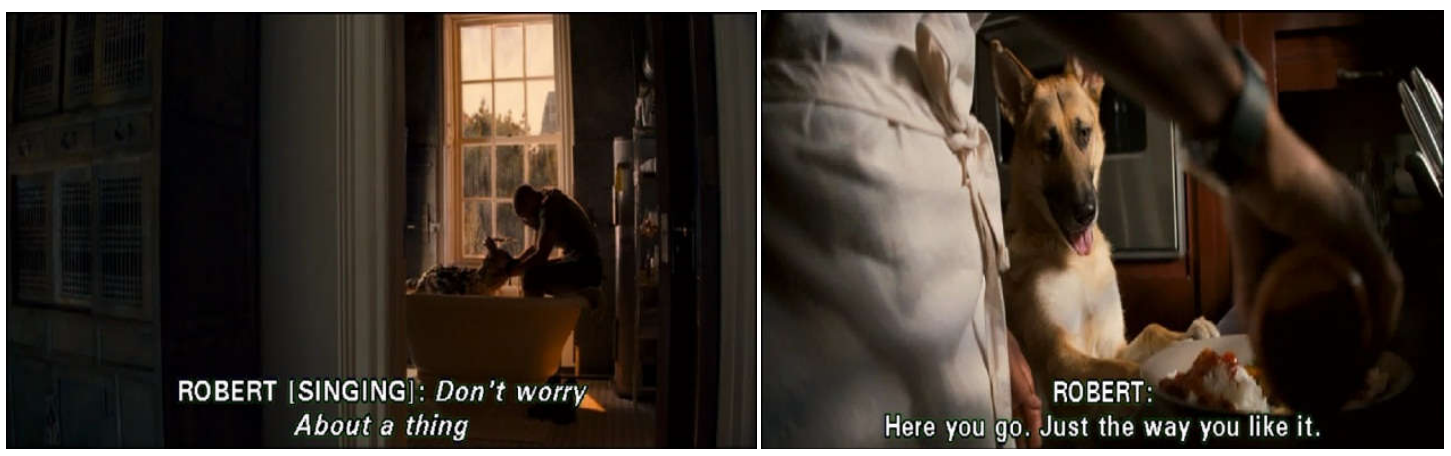

Figure 4: Robert Give Shower and Breakfast to his dog ( 00:09:06 and 00:10:38)

We can observe from the pictures above, how the clonesess of Robert Neville with his dog, Samantha. Visual signs and images as well as the picture captured carry meaning and thus have to be interpreted (Hall 5). The researcher can construct the meaning by analyzing the non-narrative aspect of the scene. From the color of the scene in the left figure, Robert and Samantha are put in the middle of the darkness, and the light is coming just from the window. The scene shows a very limited light, and it means this film is cathegorized as misteries and thrillers (Giannetti 17).

Dominant society may point out that African Americans have characteristics that separate them from other groups. Therefore, African Americans' experiences may be due to the degree of to which society perceives them as strange. African Americans are, essentially, a group of strangers. A stranger is usually perceived as an individual who is an intruder, foreigner, or a resident alien (Turner 1). When African Americans are considered as the strangers, they will not have friends from another groups. In I am Legend, Robert Neville is the only African American man survive in the New York city. He is just accompanied by his dog, Samantha. His loneliness drives him to air the announcement that he is alive, he is a survivor, and anybody can come to him.

Robert :My name is Robert Neville. I am a survivor living in New York city. I am broadcasting on All AM frequencies. I will be at the south Street Seaport everyday at midday, when the sun is highest in the sky. If you are out there. If anyone is out there, I can provide food, I can provide shelter, I can provide security. If there is anybody out there. Anybody. Please. You are not alone. (00:24:08 and 00:45:02)

The situations in society that treats African Americans as alienated, another word by definition of stranger, is still present.

African Americans are frequently portrayed with personality characteristics that are stereotypically negative. African American portrayals, the U.S. Commission on Civil Rights (1977) found that African American television portrayals typically depicted the following stereotypic personality characteristics: inferior and stupid (Carter 242). The stereotypes given from the US Commission on Civil Rights still happened and can be seen in I am Legend film. 


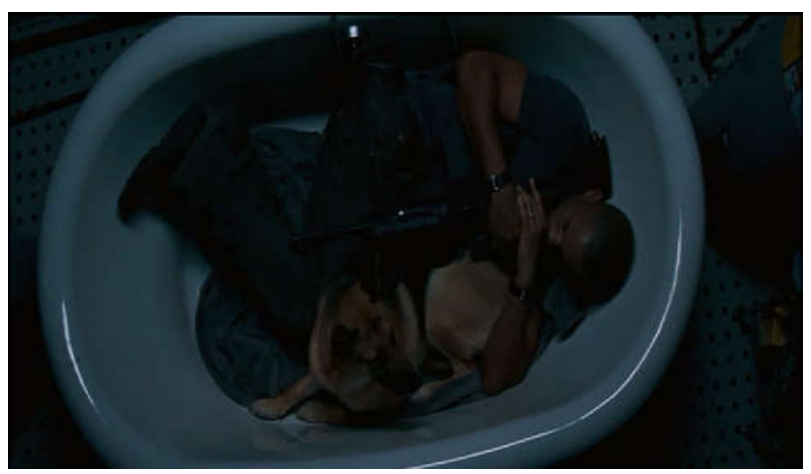

Figure 5 - Robert is sleeping in the bathtub with Samantha (00:12:37)

According to Oxford Advance Learner's Dictionary, bathtub means a large long container that we can put water in and then get into to wash our whole body (115). This screen shot is taken from the high angle. High angle reduces the importance of the subject. The subject seems harmless and insignificant when it is photographed from above (Giannetti). From this stereotype, the African American is looked as the one who afraid of threat. Whe he is threatened, he looks inferior, he is afraid and try to keep himself safe by carrying the gun so that he can defense himself from the dangerous thing surround him.

White Ameican is ambivalent toward African Americans, sometimes feeling racist, other times feeling quite friendly, and sometimes holding contradictory sentiments all at once. Moreover, many Whites tend to disguise their true feelings, knowing the social undesirability of appearing to be racist (Entman and Rojecki 46-47). It is a very common thing then if the African Americans are depicted in the binary opposition characterization in one act at once.

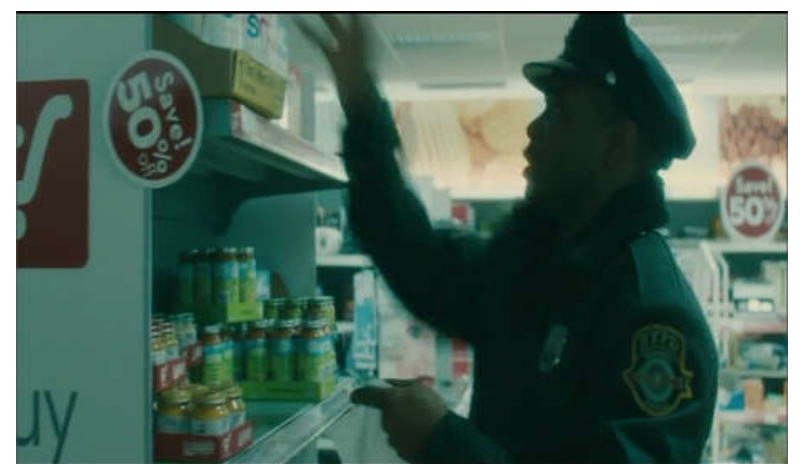

Figure 6 - The African American policeman takes some goods at the supermarket (00:16:20)

The researcher implies that even if African Americans dress and speak in a conventionally acceptable manner, employ a restrained verbal style, they cannot totally surmount the barrier posed by Whites' automatic generalizations from physical traits to moral, behavioral, and intellectual qualities and achievements (Entman and Rojecki 52). From this character, the researcher analyze that the director wants to show the binary opposition of the African Americans representation. It shows although the African American is a policeman, his act can not be presented as same as the White people, he wears the police uniform but he does the criminal thing like a thief. The meaning is that when African Americans are given the power, as a police for example, they tend to corrupt and do not fully responsible with the uniform ther wear.

Whites tend to equate African Americans and crime, and feel intensely negative emotions more than the face of Black crime than of white crime. Although Blacks are indeed more likely to commit violent crimes than Whites, the difference declined after 1970 and the general trend in Black-commited violence has been downward since the early 1970s. Furthermore, some evidences show thgat Blacks are more likely to be arrested than Whites committing similar crimes, in which case the media might be accurately representing Black's 
higher arrest rate but exaggerating the comparative rate of committing violent or drug crimes (Entmand and Rojecki 70).

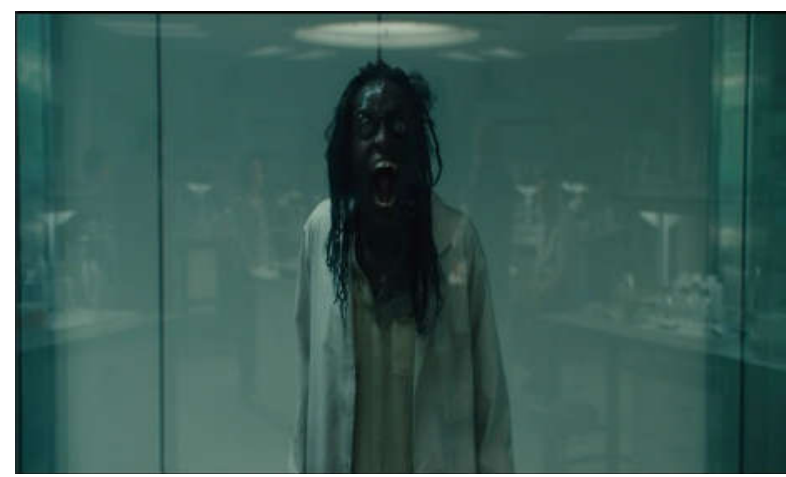

Figure 7 - The zombie in the WHO research (1:32:05)

The context and the zombie character above can be analyzed as the representation of the African American character constructionist approach. In the figure above, the zombie is arrested and kept inside the locked glass box. This is the filmmaker who wants to show how the African American is dangerous toward the society. The researcher has a unique meaning through the language. Language is therefore the second system of representation involved in the overall process of constructing meaning (Hall 4). The visual appearance of the film is one of the language of representation. The filmmaker has made specific choices of the object which is being captured (Monaco 162). The zombie is captured with such expression to show that she is in her anger, and it shows she is very aggressive.. From the expression, the researcher looks the zombie is threatening. Though Blacks have often been portrayed as physically threatening, the current Black stereotyping of criminals is an unusual phenomenon (Mauer, 1999; Russell, 2002). As a constructionist, the researcher represents that African American is threatening through the society. By looking at this case, the stereotypes of other is reflected well through the zombie character.

\section{CONCLUSION}

The representation of the African American through any media is actually not as that good, When the African Americans are represented as a good character, there has to be worse stereotype behind it. Sometimes the director does not show explicitly how the stereotypes of the African American in the reality. They tend to cover the stereotypes by showing the good representation to the society. There is nothing in reality that compels the representation of african Americans that the media offer. What we see and do not see reflects a combination of forces that, with alteration, could result in different representations that are no less defensible. However, racism is not totally disappeared. It is just goes "underground" that is racial inequality in America still becomes a major and pressing problem.

\section{REFERENCES}

1. Becker, K. ( 2010). The New World of the Post-Apocalyptic Imagination. A Thesis. California State University, Chico, Pdf file

2. Bollafi, G. (2003). Dictionary of Race, Ethnicity, and Culture. London: Sage Publication,. Print

3. Bracey, Earnest.N. (2003) On Racism.Lanham: Univeristy Press of America,. Print

4. Carter, Narissra MP. (2008) The Perceived Realism of African American Portrayals on Television. Routledge. Pdf file

5. Creswell, J.W. (2009). Research Design: Qualitative, Quantitative, and Moxed Methods Approaches 3rd ed,. California: Sage. Print 
6. Entman, Robert M and Rojecki, Andrew (2000). The Black Image in the White Mind: Media and Race in America.. The University of Chicago Press. Chicago and London. Print

7. Giannetti, Louis.(2009) Understanding Movies. 11th Ed. Prentice Hall. United States of America. Print

8. Gray, Herman S. (2005) African Americans and the Politics and Representation: Cultural Moves. University of California Press: London

9. Hall. Stuart. (2007) Representation: Cultural Representation and Signifying Practices. Sage Publication,. Print

10. Jorgensen, Carl.(1995) The Journal of Negro Education, Vol. 64, No. 3, Myths and Realities: African Americans and the Measurement of Human Abilities,. Pdf file

11. Pager, Devah and Hana Shapered. (2008) The Sociology of Discrimination. Department of Sociology, Princeton University, Princeton, New Jersey. Pdf file

12. The United States Commission on Civil Rights.(1980) Racism in America and How to Combat It. Clearinghouse Publication, Urban Series No.1. Washington DC,. Pdf file

13. Turner, Sarah D. (2002) African Americans' Experiences Of Estrangement And Alienation: A Comparative Analysis Of Georg Simmel's Essay "The Stranger". Texas Tech University. Pdf file

14. Tyndall, C. Patrick. "Celebrating African American Music and Spirituality in August Wilson's Joe Turner's Come and Gone, Ma Rainey's Black Bottm, and The Piano Lesson" University of Arkansas. Print

15. Tyson, Louis. (2006) Critical Theory Today, Second Edition. Routledge, London and New York Print

16. Warnerbros.com. Company Overview. Web http://www.warnerbros.com/ Retrieved on 10 January 2014. Online

17. Wildman. Stephanie M. (1996) Privilege Revealed: How Invisible Preference Undermines America. New York: NYU Press,. Print.

18. Wynter, Leon E. (2002) American Skin: Pop Culture, Big Business, and The End Of White America. Crown Publisher, New York,. Print. 